\title{
HAPPINESS AMONG FIRST-YEAR STUDENTS AT A COMPREHENSIVE TERTIARY INSTITUTION - AN EXPLORATORY STUDY
}

\author{
Marinda Pretorius" \\ University of Johannesburg \\ marindap@uj.ac.za
}

Received: March 2014

\author{
Derick Blaauw+ \\ North West University, Potchefstroom Campus \\ derick.blaauw@nwu.ac.za
}

Accepted: June 2014

\begin{abstract}
The 1970s saw a significant increase in the volume of research on individuals' subjective experience of well-being. The subjective well-being of university students has received less attention, however. Student well-being is important, given the widespread concern over the high dropout rates at institutions of higher learning in South Africa (Council of Higher Education, 2013; Van Zyl, 2010). The paper adds to the existing body of literature through an exposition on the possible influence of variables forthcoming from the literature, on the overall subjective well-being of first-year economics students at a comprehensive university. Variables that displayed a significant and positive contribution to subjective well-being were first-year and extended-degree students, the university being the institution of choice, feeling at home, knowing exactly how the university functions, and watching or participating in sport. Variables that were found to be significant with a negative contribution to subjective well-being levels were: worries about tests, studying less than 10 hours per week and, interestingly, living on campus.
\end{abstract}

Keywords

Happiness, subjective well-being, university students, determinants, economics.

\#Ms M Pretorius is a lecturer in the Department of Economics and Econometrics, University of Johannesburg, South Africa.

+Prof D Blaauw is an associate professor in the School of Economics, North West University, Potchefstroom Campus, South Africa 


\section{INTRODUCTION}

In theory, university students are young, dynamic, rank among the well-educated population of the society and are bound to be the adults, employees and parents of the future (Türkdoğan and Duru, 2012). The South African university landscape reveals widespread concern about a number of issues confronting it. The issue of student retention and throughput rates are of particular concern in South Africa (Van Zyl, 2010:1; Van Zyl \& Blaauw, 2012). The study of Scott, Yeld and Hendry (2007) was among the first to give prominence to this issue (Van Zyl, 2010:1). In their analysis of the 2000 cohort of students, they estimated that the national throughput rate after five years of students studying mostly three-year qualifications was as low as $30 \%$ (Scott et al., 2007).

The Council on Higher Education (CHE) (2013:45) reports similar results for a cohort analysis of the 2006 cohort: 'Five years after entering, only $35 \%$ of the 2006 cohort had graduated, including under half of the contact students. The estimated final attrition rates are $55 \%$ for the full intake and $45 \%$ for all contact students. The loss of about half of the country's small intake is unacceptable.' The impact of this state of affairs is very destructive and costly in the long run, especially in the South African context of scarce skills (CHE, 2013:45). On a macro level the result is that South Africa is not attaining the set developmental goals and on a micro-level many students are not reaching their full potential (Letseka \& Maile, 2008).

Reaching their potential in terms of success and failure in higher education is the result of a complex interplay of factors (CHE, 2013). These factors are both endogenous, that is, inherent to the higher education system itself, and exogenous, relating to social, cultural and material circumstances (Van Zyl, 2010; CHE, 2013).

The role of emotional factors in influencing student performance is also broadly acknowledged and established for South Africa by Scott et al. (2007:38-39), who remark that 'students' confidence, motivation, and general wellness may be compromised by inability to cope with the educational process they find themselves in.' The question as to how students perceive their general well-being is an important subject in terms of academic success and reaching their potential. This must be seen in the context of their broader perception as to what is important to young people in general. The typical first-year student faces a variety of social and emotional challenges that may have an impact on his or her subjective well-being (Negovan, 2010). Subjective well-being is generally defined as the individual's cognitive and affective evaluation of his life (Dave, Tripathi, Singh \& Udainya, 2011). Both internationally and in South Africa, university students are continually facing the risk of poor academic performance (Van Zyl, 2010; CHE, 2013).

International literature on the well-being of university students specifically suggests that university students all across the world regard subjective well-being, in the form of good health and overall contentment, as a key element in their lives (Diener, Diener \& Diener, 1995). However, unlike in the international research landscape, the subjective well-being and quality of life $(\rho \circ L)$ in general of university students have received little attention in the South African literature up to now (Botha, Snowball, De Klerk \& Radloff, 2013). This research is an exploratory endeavour to start opening up this research avenue.

The aim of this article is to explore possible factors that have an impact on the overall subjective well-being of university students. An exploratory enquiry into the possible determinants of subjective well-being of first-year economics students at a comprehensive 
university was used as a case study. A comprehensive university in the South Africa context can be defined as a university that offers a combination of theoretically oriented university degrees as well as vocationally oriented diplomas and degrees (HESA, 2005). Students at a comprehensive university tend to originate from a variety of backgrounds with unique characteristics and circumstances facing them outside the realm of university life. The article offers a unique contribution to the existing body of literature, as no previous studies in South Africa have been conducted in this context. This study furthermore constitutes the foundation for future studies on the perceived influence of a targeted first-year orientation programme at departmental level on the overall subjective well-being of first-year students. The hypothesis is that such a programme could play a positive role in the subjective well-being of the students. Students may well feel more in control of their destiny through this continued interaction with the academic departments in which they study.

The paper will explore the appropriate theoretical elements and literature on the issue of student success, integration and engagement on the one hand and the subjective well-being of students on the other. This is followed by an exposition of the research methodology employed in the research. The empirical analysis of this research, discussion of the results and the conclusions follows in chronological order.

\section{THEORETICAL ELEMENTS - STUDENT SUCCESS, INTEGRATION AND ENGAGEMENT}

The issue of student retention has been the objective of international research efforts for the last three decades and more (Van Zyl \& Blaauw, 2012). Tinto (2003) provides a longitudinal interactionist model, which is commonly recognised by researchers as a sound point of departure in order to understand student departure and to explain student retention behaviour (Longden, 2004; Van Zyl \& Blaauw, 2012).

Tinto's theory is multifaceted and complex. It is primarily grounded in the connections between students and their educational surroundings (Hermanowicz, 2003; Van Zyl \& Blaauw, 2012). Van Zyl and Blaauw (2012:53) provide the following summary of the basic model: 'Students need to integrate into the social and academic spheres of university life if they are to persist. Fundamental to their successful integration is the pre-entry attributes with which they arrive at university. Students derive values, intentions and commitments from these pre-entry attributes which in turn directly influence their integration into the university environment (Tinto, 1993). Family background and institutional attributes also play a vital role in student commitment.'

The literature identifies some of these pre-entry attributes (Van Zyl, 2010:84). In the South African context characteristics such as matriculation exemption, students' adeptness in Mathematics, as well as the language of tuition all have a significant effect on student success (Pretorius, Prinsloo \& Uys, 2009). Irrespective of the specific higher education environment, the extent of the effort students put into their studies influences the impact of the other variables on their chances of success (Pretorius et al., 2009).

These pre-entry attributes play an important role in the level of commitment the student has to his or her personal goals as well as that of the institution (Van Zyl, 2010:82). For students to persevere, they need to make long-term commitments in these two broad areas of involvement. Where these two commitments are not made, students are far more likely to drop out (Clift, 2003; Van Zyl, 2010:82). Furthermore, the greater the commitment in the early stages of a 
student's academic career in both, the greater the chance that the student will continue and succeed (Hermanowicz, 2003; Van Zyl, 2010:82).

Tinto's theory splits the practice of student departure into three distinct but overlapping phases (Van Zyl \& Blaauw, 2012). The separation phase is first. The student leaves the previous environment behind and he or she faces the challenges intrinsic to the new environment he or she is operating in. Second is the transition phase, during which the student starts to become part of the new environment (Van Zyl \& Blaauw, 2012). The integration phase is last. The student now becomes completely part of the new culture (Van Zyl \& Blaauw, 2012; Longden, 2004; Tinto 1993).

Academic integration is described in the literature as the degree of correspondence between the student's actual intellectual capability, participation and performance and the institution's intellectual expectations (Hermanowicz, 2003; Van Zyl \& Blaauw, 2012). Two elements in this process emerge from the literature. The first is structural. This implies the process of meeting the unambiguous standards of the university. The second is normative, implying the individual's connection with the normative academic structures (Braxton \& Lee, 2005; Van Zyl \& Blaauw, 2012).

Social integration can be defined as the scope of correspondence between the individual student's and the institution's social systems, including interpersonal involvement, extracurricular involvement and attachments (Hermanowicz, 2003; Van Zyl \& Blaauw, 2012). Social integration typically demonstrates itself in the creation of sustaining relations with peers and staff (Nicpon, Huser, Blanks, Sollenberger, Befort \& Robbinson-Kurpius, 2006). The level of social integration in turn has an interdependent relationship with the subjective well-being of students.

\section{LITERATURE REVIEW - SUBJECTIVE WELL-BEING AND STUDENTS}

There was a time when the study of well-being was at the outside edge of the study field of economics, mainly as a result of the disciplinary paradigm of logical positivism (Easterlin, 2001; Blaauw \& Pretorius, 2013). The 1970s saw a significant turnaround as the notion of happiness and its application in economics came more and more to the fore. The (re)introduction of subjective well-being into economics is seen by many to coincide with the seminal work of researchers like Richard Easterlin $(1974 ; 2001)$. The field of study gained impetus in the 1980s, especially as the result of the formative work of Diener and Dave et al. (2011).

The comprehensive body of literature on subjective well-being over the last decade has revealed that the concept is connected with a range of social, economic, and cultural characteristics of nations (Diener, Diener \& Diener, 2009). A widely cited discussion of the factors emerging from known research is offered in Diener, Suh, Lucas and Smith (1999). Frey and Stutzer (2002) and Dolan, Peasgood and White (2008) also provide reviews, which are widely acknowledged and quoted, on the extensive economics literature on the determinants of the well-being concept. South African studies on subjective well-being include important recent work by Booysen and Botha (2011) and Ebrahim, Botha and Snowball (2011) and Botha et al. (2013). The research conducted by these authors was preceded by shaping work in a South African context by Valerie Møller and a number of co-researchers over a period of 20 years and more. The body of literature includes Møller and Schlemmer (1989), Møller (1998), Møller and Saris (2001) as well as Møller and Dickow (2002). 
The study of well-being for the most part falls into two strands of research. The first is the hedonic approach and the second is termed the eudaimonic approach (Negovan, 2010). The eudaimonic approach describes well-being as human potential. When potential is realised, it leads to a person being able to function optimally (Negovan, 2010). The literature on psychological and social well-being reflects the eudaimonic approach.

The hedonic approach, on the other hand, sees and defines well-being in terms of happiness and of the experience of pleasure combined with the absence of pain. This is where the literature on subjective well-being and this study fits in (Negovan, 2010).

A significant body of literature that investigates the determinants of quality of life ( $\mathrm{OoL}$ ) among university and college students is available. It is however primarily focused on a developed country context (Botha et al., 2013). The South African context has not received similar attention. Møller (1996) examined the dynamics of life satisfaction among University of KwaZulu-Natal students in general. Botha et al. (2013) focused their attention on the satisfaction with residence life in particular. The international and limited South African literature suggests that any attempt to model the determinants of students' subjective wellbeing must make provision for a wide range of factors. These relate to student attributes and institutional attributes (Botha et al., 2013). Student attributes includes demographic and other variables such as race, sex, sexual orientation, age, socioeconomic status, self-esteem, drug and alcohol use, learning style, and academic achievement. Factors emanating from the institutions refer to issues such as living or housing arrangements, social spaces and leisure activities as well as the culture prevalent on the campus in questions (Chow, 2005; Botha et al., 2013).

The factors identified in the literature that possibly affect students' subjective well-being start with the fulfilment of their basic needs. The key assumption of need theories is that happiness is felt only if human needs can be fulfilled sufficiently (Türkdoğan \& Duru, 2012). Furthermore, Türkdoğan and Duru (2012) show that the basic needs of students significantly predict subjective well-being. This applies to all dimensions of basic needs. The needs for freedom, fun and power came out as stronger predictors of subjective well-being in university students than the other basic needs (Türkdoğan \& Duru, 2012). In a study among Canadian students, Chow (2005) found that housing conditions were positive and statistically significant determinants of general quality of life. The size of the impact was smaller than factors like self-esteem, relationship with a 'significant other', and socioeconomic status (Botha et al., 2013).

Theory suggests that issues such as achievement or impaired social functioning must also be viewed in the context of basic needs such as their financial and accommodation problems. In addition, the specific demands and pressure of academia is also important, especially the fear of non-completion (Longden, 2008; Negovan, 2010). Additional problems that may accentuate the underlying risk of non-completion are insufficient prior information about the programme and/or the institution, and concerns regarding the financing of studies, accommodation and transport (Longden, 2008). Botha et al. (2013) conclude that it is accepted that activities and conditions outside the classroom can facilitate academic success, as well as the achievement of other necessary social outcomes. These include 'social competence, autonomy, self-awareness, and appreciation of human diversity' (Kuh, 1995:124; Botha et al., 2013).

An interesting and almost unexpected problem found to complicate the seemingly idyllic life of students is, in fact, 'over-engagement' (Eckersley, 2011). Eckersley (2011) quotes a recent Australian study which found that $48 \%$ of university students were psychologically distressed. In fact, many were at significant risk of developing a mental disorder of some kind. Results of 
national surveys of American college students reveal similar characteristics. Up to $90 \%$ of American college students report that they experienced a sense of feeling overwhelmed by all they had to do, feeling exhausted, anxiousness, anger and depression. All of this makes it difficult to function (Eckersley, 2011).

Eckersley (2011) also reports on the Australian Government's 'National Conversation' with young people. The results clearly indicate the importance of health and well-being in the lives of the youth, particularly mental health, body image, sexual health, and the absence of drug and alcohol problems. The individual's own perceptions are seen in relation to the strength of selfesteem and self-knowledge, coupled with the individual's ability to think positively or negatively (Crondahl \& Eklund, 2012). Complementary issues mentioned were stress, personal expectations of the future and health behaviour (diet, smoking, drug and alcohol use, etc.). Coupled with this is the importance of other exogenous factors.

Türkdoğan and Duru (2012: 2444) sum up the issue of subjective well-being of students as follows: 'It can be said that the students who have the ability to make choices and to express themselves freely, ... who feel themselves worthy and successful, who have enough safety and shelter conditions, and who have good relationships with special people in their lives, are more close to happiness than the others.'

The variables identified in the literature constitute the backbone of the investigation into the possible contributing factors in terms of the subjective well-being of first-year economics students at a comprehensive university. In addition, the possible contribution of a targeted first-year orientation programme is included in the analysis. The research method employed in order to conduct the investigation is discussed next.

\section{RESEARCH METHODOLOGY}

The study followed a survey-based research approach to explore the possible factors contributing to the subjective well-being of first-year economics students. The role of the orientation programme for first-year students in the Economics Department in terms of students' subjective well-being was also probed, with the aim of establishing a future research agenda to study the possible impression of such an intervention in terms of subjective wellbeing.

Available demographic data on the first-year economics students was supplemented by a purposely developed survey instrument. Studying the literature on student retention and subjective well-being of students accentuated the need to involve the academic development and support centre at the institution. The authors were fortunate that the director of the centre completed an important doctoral study on the topic of student retention at the institution (see Van Zyl, 2010). The director of the centre was contacted and the research project was discussed with him. He graciously gave permission for the questions contained in the student profile questionnaire that he developed for his doctorate to be included in the survey instrument (Van Zyl, 2010). This contribution was extremely valuable, as it created the possibility of continuing this research agenda in future and embedding the two research agendas, which would allow for synergy in future research efforts. The survey component therefore benefitted significantly from the fact that it was developed with the assistance and permission of the director of the academic development and support centre at the institution. 
After the development of the questionnaire, it was tabled to the chairperson of the faculty ethics committee. Permission was granted to deploy the survey instrument. All accompanying ethical considerations were strictly adhered to during the conducting of the study.

The envisaged research population consisted of 2200 first-year students taking the generic first-year module in economics as part of the degree or extended degree that they were enrolled for. A senior tutor was trained and assisted in the collection of the data in the various tutorial classes of the first-year students. A pilot-run of the study was conducted in order to identify any ambiguous questions and other possible problems in the survey instrument. The senior tutor asked the students whether they were willing to participate in the study, and the aim and objectives of the study were explained to them.

The data was collected in August 2013, was captured and then cleaned in order to provide a sample data set for the empirical analysis. The final sample size of the research consisted of 529 students who completed questionnaires in good order. This number represents just more than $24 \%$ of the research population.

The quantitative analysis was supplemented by a qualitative thematic analysis (content analysis) of the open-ended questions of the survey instrument. The following section provides the results and discussion of the results.

\section{DATA AND VARIABLES}

\subsection{Descriptive statistics}

The principal variable of concern is the measure of happiness. In the literature this is commonly measured by a specific form of a Likert scale. The National Income Dynamics Study (NIDS) survey chose the following question (M5) in the first wave of the adult questionnaire as the basis for self-reported satisfaction or subjective well-being: "Using a scale of 1 to 10 where 1 means "Very dissatisfied" and 10 means "Very satisfied", how do you feel about your life as a whole right now?' (NIDS, 2008:26). This study used similar wording in the survey instrument and the variable obtained formed the foundation for the investigation that follows. The variable was labelled as 'Happiness'.

Analysing the dependent variable reveals the distribution (presented in FIGURE 1 below) and it reveals an approximate normal distribution, but clustered among the higher end of the spectrum of answers to the survey question, indicating that the average respondent at this institution is relatively happy. 


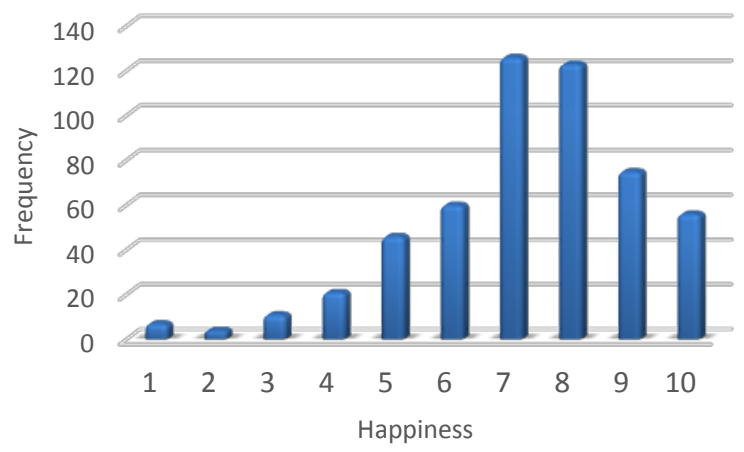

FIGURE 1: Distribution of life-satisfaction among first-year economic students at a comprehensive institution, 2013

Source: Survey data

TABLE l provides a descriptive overview of the social and demographic characteristics of the respondents. All respondents were South African-born.

\section{TABLE 1: Characteristics of respondents}

\begin{tabular}{lr}
\hline Demographic characteristics & No. (\%) \\
\hline Gender & $209(39.5 \%)$ \\
Male & $320(60.5 \%)$ \\
Female & \\
Race & $412(77.9 \%)$ \\
African & $24(4.5 \%)$ \\
Coloured & $53(10 \%)$ \\
White & $35(6.6 \%)$ \\
Indian / Asian & $5(1 \%)$ \\
Other & \\
Language & $206(38.9 \%)$ \\
English & $36(6.8 \%)$ \\
Sesotho & $48(9.1 \%)$ \\
Sepedi & $99(18.7 \%)$ \\
Isizulu & $9(1.7 \%)$ \\
Isindebele & $26(4.9 \%)$ \\
Xhitsonga & $21(4 \%)$ \\
Afrikaans & $35(6.6 \%)$ \\
Setswana & $22(4.2 \%)$ \\
Isixhosa &
\end{tabular}




\begin{tabular}{lc}
\hline Demographic characteristics & No. (\%) \\
\hline Tshivenda & $15(2.8 \%)$ \\
SiSwati & $11(2.1 \%)$ \\
Other & $1(0.2 \%)$ \\
Home Province & \\
Gauteng & $294(55.6 \%)$ \\
Mpumulanga & $51(9.6 \%)$ \\
KwaZulu-Natal & $54(10.2 \%)$ \\
Eastern Cape & $19(3.6 \%)$ \\
Limpopo & $75(14.2 \%)$ \\
North West & $23(4.3 \%)$ \\
Free State & $11(2.1 \%)$ \\
Northern Cape & $1(0.2 \%)$ \\
Western Cape & $1(0.2 \%)$ \\
\hline
\end{tabular}

Source: Surveydata

\section{6. عCONOMETRIC METHOD AND EMPIRICAL RESULTS}

\subsection{Method}

Researchers from different fields of specialisation use different estimation techniques in empirical studies of subjective well-being or happiness (Ferrer-i-Carbonell and Frijters, 2004). Psychologists and sociologists typically use Ordinary Least Squares (OLS) regressions, while economists mostly use ordered response models due to the ordered nature of the dependent variable. Some authors employ both estimation techniques in order to indicate that the research results are not biased by the particular technique used in the analysis (Stevenson \& Wolfers, 2009). In the case of single surveys, and without the option of panel data, researchers prefer to quote OLS results for the ease of interpretation of coefficients (Mackerron, 2012; Bartram, 2012). This paper, therefore, follows this practice - i.e. estimating both OLS and ordered probit models. The OLS coefficients are used mainly for interpretation.

The basic approach to specifying a well-being function is to include basic variables and a range of context-specific variables related to the literature. Basic variables in this study included gender, race, degree studied and age. Other context-specific explanatory variables included: the attendance of a first-year seminar and experience; basic-need variables such as housing, transport, food security and friendships; stress in terms of tests; class attendance; sport and cultural attendance and participation; and the time spent on studying. TABLE 2 summarises the explanatory variable used in the empirical analysis. 
TABLE 2: Explanatory variables

\begin{tabular}{|c|c|}
\hline Variable & Explanation \\
\hline Age & $\begin{array}{l}\text { Age of students during the time of the survey. The squared value was } \\
\text { used in the empirical models. }\end{array}$ \\
\hline Choice & Whether the university was the institution of choice or not. \\
\hline Contact & $\begin{array}{l}\text { Personal contact was made with either a lecturer and/or tutor } \\
\text { during the academic year. }\end{array}$ \\
\hline Culture & Attendance at or participation in cultural events. \\
\hline Degree & $\begin{array}{l}\text { Respondents were categorised according to the degree that they are } \\
\text { enrolled for - B.Com degrees in Economics and Econometrics, } \\
\text { Accounting, Finance or other B.Com degrees, Bachelors of } \\
\text { Accounting, BA degrees or other specified degrees. }\end{array}$ \\
\hline Distance Campus & $\begin{array}{l}\text { Distance of home from campus - on campus, within walking } \\
\text { distance, a short drive away ( } 30 \text { minutes or less) or a long drive away } \\
\text { (more than } 30 \text { minutes). }\end{array}$ \\
\hline Expect & Understanding of what is expected by lecturers. \\
\hline $\begin{aligned} & \text { Year of study } \\
& \text { - } \text { First-year } \\
& \text { - } \text { Extended } \\
& \text { - } \text { Repeaters }\end{aligned}$ & $\begin{array}{l}\text { Respondents were classified according to their year of study - first } \\
\text { year of study, students originating from the extended degree } \\
\text { (students that completed a foundation phase year before the } \\
\text { current academic year) and students repeating the module. }\end{array}$ \\
\hline Food Problems & Any type of food problems experienced. \\
\hline Friends & Respondents that have made friends at the university. \\
\hline Fys & $\begin{array}{l}\text { Attendance of the First Year Seminar (FyS) sessions in the two weeks } \\
\text { before lectures commenced. }\end{array}$ \\
\hline Gender & Male or female. \\
\hline Happy Live & Happiness in terms of current residence. \\
\hline Home & Feeling at home at the university. \\
\hline Language & $\begin{array}{l}\text { Language predominantly spoken by the respondent - English, } \\
\text { Sesotho, Sepedi, Isizulu, Isindebele, Xhitsonga, Afrikaans, Setswana, } \\
\text { Isixhosa, Tshivenda, SiSwati, Shona and other. }\end{array}$ \\
\hline $\begin{array}{ll}\text { Live } & \\
\text { - } & \text { On campus } \\
\text { - } & \text { Home } \\
\text { - } & \text { Commune } \\
\text { - } & \text { Family } \\
\text { - Other }\end{array}$ & $\begin{array}{l}\text { Place of residence - On campus, home, commune, with family or } \\
\text { other. }\end{array}$ \\
\hline Missed & $\begin{array}{l}\text { The number of lectures and tutorials that were missed in a normal } \\
\text { week. }\end{array}$ \\
\hline
\end{tabular}




\begin{tabular}{|c|c|}
\hline Variable & Explanation \\
\hline Province & $\begin{array}{l}\text { All respondents were from South Africa; categories for each of the } 9 \\
\text { provinces were included - Gauteng, Mpumalanga, KwaZulu-Natal, } \\
\text { Eastern Cape, Limpopo, North West, Free State, Northern Cape, } \\
\text { Western Cape. }\end{array}$ \\
\hline Race & African, Coloured, White, Indian/Asian and other. \\
\hline Sport & Attendance or participation in sports events. \\
\hline $\begin{array}{l}\text { Study Hours } \\
\begin{array}{ll}\text { - } & \text { Less than } 10 \\
\text { - } & 10 \text { to } 15 \\
\text { - } & 15 \text { to } 25 \\
\text { - } & 25 \text { to } 35 \\
\text { - } & \text { More than } 35\end{array}\end{array}$ & $\begin{array}{l}\text { Hours per week spend studying outside of class time - less than } 10 \\
\text { hours, } 10 \text { to } 15 \text { hours, } 15 \text { to } 25 \text { hours, } 25 \text { to } 35 \text { hours and more than } \\
35 \text { hours. }\end{array}$ \\
\hline Test Worries & Worries about upcoming tests. \\
\hline Transport & $\begin{array}{l}\text { Type of transport mostly used to get to campus - taxi, private car, } \\
\text { walking or other. }\end{array}$ \\
\hline Transport Problems & Problems experienced with transport to campus. \\
\hline University function & Understanding of how things work at the university. \\
\hline
\end{tabular}

Source: Survey Data

The ordered probit model is specified as (Botha et al., 2013):

$$
y_{i}=\delta X_{i}+\varepsilon_{i}
$$

where $y_{i}$ is the 10 -point variable that represents Happiness, $X_{i}$ is a $(k \times 1)$ vector of basic and context-specific variables, $\delta$ is a vector of unknown parameters and $\varepsilon_{i}$ is a randomly distributed error term.

\subsection{Results}

As a starting point all explanatory variables as defined in TABLE 2 were included in the model. Various variables were found to be statistically insignificant in both the OLS and ordered probit models and were subsequently removed. The final regression results are reported in Table 3.

\section{TABLE 3: Concluding estimated well-being model}

\begin{tabular}{lccccccc}
\hline & \multicolumn{2}{c}{ OLS } & \multicolumn{3}{c}{ Ordered probit } \\
& Coef & Prob & & Coef & Prob & \\
\hline C & 3.069554 & 0.0019 & $\star \star \star$ & & & \\
First-Year & 2.528904 & 0.0043 & $\star \star \star$ & 1.388345 & 0.0081 & $\star \star \star$ \\
Extended & 2.523852 & 0.0055 & $\star \star \star$ & 1.414975 & 0.0086 & $\star \star \star$
\end{tabular}




\begin{tabular}{|c|c|c|c|c|c|c|}
\hline Choice & 0.600166 & 0.0031 & $\star \star \star$ & 0.0347767 & 0.0034 & $\star \star \star$ \\
\hline Fys & 0.107998 & 0.5509 & & 0.065444 & 0.5380 & \\
\hline Friends & 0.473702 & 0.1075 & & 0.243451 & 0.1573 & \\
\hline Home & 0.686904 & 0.0003 & $\star \star \star$ & 0.394101 & 0.0004 & $\star \star \star$ \\
\hline Sport & 0.469632 & 0.0133 & $\star \star$ & 0.297122 & 0.0080 & $\star \star \star$ \\
\hline University Function & 0.97049 & 0.0020 & $\star \star \star$ & 0.577591 & 0.0017 & $\star \star \star$ \\
\hline Test Worries & -0.611435 & 0.0002 & $\star \star \star$ & -0.360029 & 0.0002 & $\star \star \star$ \\
\hline Expect & -0.408718 & 0.1548 & & -0.274000 & 0.1065 & \\
\hline Study less than 10 hours & -0.340175 & 0.0678 & * & -0.195348 & 0.0746 & * \\
\hline Live on Campus & -0.522788 & 0.0323 & $\star \star$ & -0.32339 & 0.0244 & $\star \star$ \\
\hline R-squared & & 0.157695 & & & & \\
\hline Adjusted R-squared & & 0.138069 & & & & \\
\hline Pseudo R-squared & & & & & 0.04175 & \\
\hline
\end{tabular}

Source: Estimation Results

$\star, \star \star, * \star \star 10 \%, 5 \%, 1 \%$ level of significance, respectively

Many of the variables expected to be significant according to the standard subjective well-being literature were insignificant in this study, such as age, race and gender. This may be explained by the context-specific nature of the investigation as opposed to a broad South African study (see for example Blaauw and Pretorius, 2013). The students in this comprehensive institution are a homogeneous group to a large extent.

The First-Year Seminar was not significant. There is, however, an important caveat here. The study was done six months after the conclusion of the seminar. The effect of the First-Year Seminar may be more pronounced just after the intervention. This must be tested and forms part of the future research agenda emanating from this exploratory study.

The following variables had a significant and positive contribution to subjective well-being: first-year and extended-degree students; the university being the institution of choice; feeling at home; knowing exactly how the university functions. These findings resonate well with international research in the fields of student success, integration and engagement. Knowing how the university functions, for example, will assist the new student to make that all-important initial adjustment to his new surroundings. The literature suggests that this is an important element to ensure integration, commitment to the goal of the student and his/her ultimate success (Braxton \& Hirschy, 2005; Van Zyl, 2010:85). Research in the United Kingdom also confirmed that if students did not value the institution they studied at or the programme for which they enrolled, they were less likely to persist with their studies compared to those who did (Yorke, 2007).

An interesting result was the positive and significant role of taking part or watching sport. However, the issue of endogeneity must be taken into account. For example, is a student happy because he takes part in or watches sport, or is it a case of taking part or watching because he or she is happy at that point in time? Questions like these will form part of a qualitative angle 
that can be probed in future research and linked to the interrelated process of academic and social integration (Van Zyl, 2010:85).

Explanatory variables that were found to be significant with a negative contribution to subjective well-being were: worries about tests, studying less than 10 hours per week and, interestingly, living on campus. Although the university choice variable was found to be positive and statistically significant, living on campus is negatively related to students' happiness. This result seems counterintuitive. Perhaps this is a result of overcrowding on campus, with infrastructure and facilities being under pressure as a result. One student suggested that persistent orientation practices in hostels may also be a possible reason. This is again an important issue that needs to be explored by qualitative research. Such a research methodology may include participatory techniques such as focus group discussions and individual interviews, using Tesch's framework of systematic qualitative data analysis (Tesch, 1990).

\section{CONCLUDING REMARKS AND POSSIBLE AREAS FOR FURTHER RESEARCH}

The variables found to be of significance for subjective well-being among first-year economics students are context-specific, given the homogeneous nature of the students in terms of the subject. The findings align well with the literature on the subjective well-being of students. The findings of the role of location on campus are, however, surprising and need to be analysed further.

One of the suggestions flowing from the study is the need to identify at-risk students and then determine what interventions can be instituted that specifically target factors that may have a negative impact on their well-being and indirectly on their chances of completing their studies successfully. There are, however, no quick-fix solutions. Each institution of higher learning must develop ways of growing the chances of individual students' success, depending on their unique circumstances. The international literature suggests that early assessment of the well-being of students is the cornerstone of such attempts. Investigating non-traditional ways of offering university services - for example, offering it in a group setting using informal seminars - can also assist students. Examples include the adoption of skills and techniques to cope with the loneliness and distance from family and loved ones (McLachlan and Justice, 2009).

In order to effectively probe the effect of the targeted first-year intervention in the form of the first-year seminar, the survey must be administered before the seminar and then repeated thereafter. This comparison will provide prima facie evidence in terms of the impact on the subjective well-being of first-year economics students. This research can then be extended into a faculty-wide research project.

Another important area for future studies indirectly emerging from the research is the differences that may exist in the perception of subjective well-being between first-generationand second-generation students, as well as the urban/rural origin of the students. Van Zyl (2010) classifies these elements as important concepts in terms of the cultural capital a student arrives with at an institution of higher learning and which can play a role in the adjustment process. The study of the subjective well-being associated with students' cultural capital is an important step in understanding the world our country's students are functioning in. Only if we improve our appreciation of this world and the link between subjective well-being and students' ability to adjust can we design interventions to assist them in making a success of 
their studies and providing government with a suitable private and social return on their considerable investment in the higher education sector.

\section{Acknowledgements}

The authors want to acknowledge the invaluable contribution of Dr André van Zyl, Director of the Academic Development and Support centre at the institution where the research was conducted, in the development of the survey instrument. He graciously gave permission to include questions contained in the student profile questionnaire that he developed for his doctorate in the survey instrument. The research benefitted significantly from this.

A previous version of this paper was presented at the Biennial Conference of the Economic Society of South Africa, Bloemfontein, 25 - 27 September 2013. We appreciate all the valuable comments and discussion at the conference, in particular that of $\mathrm{Mr}$ Ferdi Botha of Rhodes University. The same applies to the valuable comments received from the anonymous referees of the journal. All mistakes remain our own.

\section{LIST OF REFERENCES}

Bartram, D. (2012). Migration, return and happiness in Romania. European Societies, (forthcoming).

Blaauw, P.F. \& Pretorius, A.M. (2013). The determinants of subjective well-being in South Africa - an exploratory enquiry. Journal of Economic and Financial Sciences, 6(1), pp. 179-194.

Booysen, F. \& Botha, F. (2011). The gold of one's ring is not far more precious than the gold of one's heart: Reported happiness among married and cohabitating South African adults. Paper presented at the bi-annual conference of the Economic Society of South Africa, 4-7 September 2011, University of Stellenbosch, South Africa.

Botha, F., Snowball, J., De Klerk, V. \& Radloff, S. (2013). Determinants of Student Satisfaction with Campus Residence Life at a South African University. Economic Research Southern Africa (ERSA) (Working paper no. 388).

Braxton, J.M. \& Hirschy, A.S. (2005). Theoretical developments in the study of college student departure, In Seidman, A (Ed). College student retention: Formula for student success. American Council of Education, Westport, Connecticut, Praeger Publishers.

Braxton, J.M. \& Lee, S.D. (2005). Toward reliable knowledge about college student departure, In Seidman, A ( $(\mathrm{d})$. College student retention: Formula for student success. American Council of Education, Westport, Connecticut, Praeger Publishers.

Chow, H. (2005). Life satisfaction among university students in a Canadian prairie city: A multivariate analysis. Social Indicators Research, 70, pp. 139-150.

Clift, P. (2003). Student support and retention: Models of explanation and good practice.

Manchester. University of Manchester.

Council on Higher Education (CHE) (2013). A proposal for undergraduate curriculum reform in South

Africa: The case for a flexible curriculum structure, Report of the Task Team on Undergraduate

Curriculum Structure. [Online] Available:

http://www.che.ac.za/sites/default/files/publications/Full_Report.pdf. (Accessed 14 May 2014). 
Crondahl, K. \& Eklund, L. (2012). Perceptions on health, well-being and quality of life of Balkan Roma adolescents in West Sweden. Romani Studies, 22(2), pp. 153-173.

Dave, R., Tripathi, K.N., Singh, P. \& Udainya, R. (2011). Subjective well-being, locus of control and general self-efficacy among university students, Amity Journal of Applied Psychology, 2(1), pp. 2832.

Diener, E., Diener, M., \& Diener, C. (1995). Factors predicting the subjective well-being of nations. Journal of Personality and Social Psychology, 69, pp. 851-864.

Diener, E., Suh, E.M., Lucas, R.E. \& Smith, H.L. (1999). Subjective well-being: three decades of progress. Psychological Bulletin, 125, pp. 276-302.

Diener, E., Diener, M. \& Diener, C. (2009). Factors predicting subjective well-being of Nations. Social indicators research series 38, DOI 10.10077978-90-481-2352-0_3, pp. 43-70.

Dolan, P., Peasgood, T. \& White, M. (2008). Do we really know what makes us happy? A review of the economic literature on the factors associated with subjective well-being, Journal of Economic Psychology, 29, pp. 94-122.

Easterlin, R.A. (1974). Does economic growth improve the human lot? Some empirical evidence. In David, P.A. \& Reder, M.W. (eds.) Nations and households in economic growth: Essays in honour of Moses Abramovitz. New York: Academic Press (pp. 89-125).

Easterlin, R.A. (2001). Editorial: Subjective well-being and economic analysis: a brief introduction. Journal of Economic Behavior \& Organization, 45, pp. 225-226.

Ebrahim, A., Botha, F. \& Snowball, J. (2011). The determinants of happiness among race groups in South Africa. Paper presented at the biannual conference of the Economic Society of South Africa (ESSA), University of Stellenbosch, South Africa, 4-7 September 2011.

Eckersley, R. (2011). A new narrative of young people's health and well-being. Journal of youth Studies, 14(5), pp. 627-638.

Ferrer-i-Carbonell, A. \& Frijters, P. (2004). How important is methodology for the estimates of the determinants of happiness? Economic Journal, 114(July), pp. 641-659.

Frey, B. \& Stutzer, A. (2002). What can economists learn from happiness research? Journal of Economic Literature, 40, pp. 402-435.

Hermanowicz, J.C. (2003). College attrition at American research universities. Agathon Press.

Higher Education of South Africa (HESA) (2005). SA Higher education. [Online] Available: http://web.archive.org/web/20050301015907/http://www.sauvca.org.za/highered/. (Accessed 13 February 2014).

Kuh, G. (1995). The other curriculum: Out-of-class experiences associated with student learning and personal development. Journal of Higher Education, 66 (2), pp. 121-155.

Letseka, M. \& Maile, S. (2008). High university drop-out rates: a threat to South Africa's future. Human Sciences Research Council, Pretoria, South Africa.

Longden, B. (2004). Interpreting student early departure from higher education through the lens of cultural capital. Tertiary Education and Management, 10, pp. 121-138.

Longden, B. (2008). The first-year experience of higher education in the UK, final report. The Higher Education Academy, York, United Kingdom. 
Mackerron, G. (2012). Happiness economics from 35,000 feet. Journal of Economic Surveys, 26(4), pp. 705-735.

McLachlan, D.A. \& Justice, J. (2009). A Grounded Theory of International Student Well-being. Journal of Theory Construction \& Testing, 13(1), pp. 27-32.

Møller, V. \& Schlemmer, L. (1989). South African Quality of Life: A Research Note. Social Indicators Research, 21(3), pp. 279-291.

Møller, V. (1996). Life satisfaction and expectations for the future in a sample of university students: A research note. South African Journal of Sociology, 27 (1), pp. 16-26.

Møller, V. (1998). Quality of life in South Africa: Post-apartheid trends. Social Indicators Research, 43(1-2), pp. 27-68.

Møller, V. \& Saris, W.E. (2001). The Relationship between Subjective Well-being and Domain Satisfactions in South Africa. Social Indicators Research, 55(1), pp. 97-114.

Møller, V. \& Dickow, H. (2002). The Role of Quality of Life Surveys in Managing Change in Democratic Transitions: The South African Case. Social Indicators Research, 58(1-3), pp. 267-292.

Negovan, V. (2010). Dimensions of students' psychosocial well-being and their measurement: Validation of a students' Psychosocial Well Being Inventory. Europe's Journal of Psychology, 2, pp. 85104.

NIDS. (2008). Adult questionnaire, National Income Dynamics Survey. SALDRU, UCT School of Economics, Cape Town.

Nicpon, M.F., Huser, L., Blanks, E.H., Sollenberger, S., Befort, C \& Robbinson-Kurpius, S.E. (2006). The relationship of loneliness and social support with college freshmen's academic performance and persistence. Journal of College Student Retention, 8(3), pp. 345-358.

Pretorius, A.M., Prinsloo, P. \& Uys, M.D. (2009). Student performance in introductory microeconomics at an African open and distance learning institution. Africa Education Review, 6(1), pp. 140-158.

Scott, I., Yeld, N. \& Hendry, J. (2007). A case for improving teaching and learning in South African higher education. Higher Education Monitor No. 6, Pretoria: Council on Higher Education. [Online] Available: http://www.che.ac.za/documents/d000155/index.php. (Accessed 12 May 2014).

Stevenson, B. \& Wolfers, J. (2009). The Paradox of Declining Female Happiness. American Economic Journal: Economic Policy, 1(2), pp. 190-225.

Tesch, R. (1990). Qualitative research: Analysis types and software tools. New York: Falmer Press.

Tinto, V. (1993). Leaving College: Rethinking the causes and cures of student attrition, 2nd edition. Chicago: University of Chicago Press.

Tinto, V. (2003). Establishing conditions for student success. In Improving completion rates amongst disadvantaged students. Edited by Thomas, L., Cooper, M. \& Quinn, J. Stoke on Trent, UK: Trentham books.

Türkdoğan, T. \& Duru, દ. (2012). The Role of Basic Needs Fulfilment in Prediction of Subjective WellBeing among University Students. Educational Sciences: Theory \& Practice, 12 (4), pp. 2440-2446.

Van Zyl, A. (2010). The predictive value of pre-entry attributes for student academic performance in the South African context. D-Ed Phil thesis, University of Johannesburg.

Van Zyl, A. \& Blaauw, P.F. (2012). An Integrated Project Aimed at Improving Student Success. Africa Education Review, 9(3), pp. 50-68. 
Yorke, M. (2007). 'The first year experience: successes and challenges'Paper presented at Seminar Series on Mass Higher Education in UK and International Contexts, Kingston University, Surrey, United Kingdom, 29/05/07 - 30/05/07. 
Pretorius \& Blaauw 